\title{
Opsonization of Salmonella enteriditis Lipopolysaccharide in Sickle Cell Disease
}

\author{
RONALD J. FIELD, GARY D. OVERTURF, ${ }^{(24)}$ AND ROBERT STRUNK \\ Deparıment of Pediatrics, University of Southern California, Los Angeles, California /R. J. F., G. D. O.J. and Department \\ of Pediatrics /R. S.J, National Jewish Hospital and Research Center. Denver. Colorado, USA
}

\begin{abstract}
Children with sickle cell disease (SCD) have an increased incidence of severe Salmonella infections $(5,17)$ in addition to those infections caused by encapsulated bacteria $(1,11,15,16)$. Functional asplenia, generalized reticuloendothelial dysfunction, defective opsonization abnormalities of the alternative pathway of complement activation, specific neutrophil dysfunction, tuftsin deficiency, and local host factors, such as thrombosis and infarction, have all been proposed as possible explanations for enhanced susceptibility to bacterial infections (6). The study reported here was performed to evaluate the in vitro opsonization of Salmonella lipopolysaccharide (LPS) by sera from children with SCD by techniques not previously utilized in this group of patients. Attempts were made to clarify the function of the alternative pathway of complement activation in opsonization of Salmonella LPS and to relate the function of this system to predisposition to Salmonella infection, if any, in the child with SCD.
\end{abstract}

\section{MATERIALS AND METHODS}

\section{PATIENTS SERUM SAMPLES}

Serum was collected from 36 children with SCD ( 21 females and 15 males) with a mean age of 8.5 years (range, 12 months to 15 years). Diagnosis of SCD was confirmed by hemoglobin electrophoresis, and all were SS hemoglobin genotype. This group of SCD patients included children who had had documented episodes of sepsis (3), bacterial meningitis (2), or chronic Salmonella osteomyelitis (1). Thirty-three well black children ( 13 females and 20 males) with a mean age of 8.9 years (range, 11 months to 17 years) provided control sera; of these children, seven had heterozygous AS or AC hemoglobin genotypes. All sera were obtained from children who were clinically free of infection at the time of venipuncture, but three children with $S C D$ were in pain crisis at the time of venipuncture. Serum was frozen at $-70^{\circ} \mathrm{C}$ within $1 \mathrm{hr}$ collection. Human C2-deficient serum was donated by Dr. Michael Glovsky of the Kaiser Permanente Medical Center, Los Angeles, CA.

\section{PHAGOCYTE PREPARATION AND COLLECTION}

Blood for phagocytes was obtained from patients hospitalized for a variety of acute and chronic infectious diseases on the Los Angeles County-University of Southern California Medical Center Communicable Disease Service in National Institutes of Health anticoagulant formula 4 in a ratio of four parts blood to one part ant.coagulant. Leukocytes were collected by dextran sedimentation according to the method of Stossel (18).

\section{SERUM-DEPENDENT OPSONIZATION OF SALMONELLA enteritidis LPS}

Time-fixed opsonization and phagocytosis. Opsonization ability of each individual serum was assessed by quantitation of ingestion of a LPS-paraffin oil emulsion containing the dye oil red O (ORO) by phagocytes utilizing the technique of Stossel (18) with the single modication that $S$. enteritidis LPS (Difco Laboratories, Detroit, MI) was substituted for Escherichia coli LPS. All experiments were performed blind and in duplicate.

Preparation of Paraffin Oil LPS Emulsion. ORO $(5 \mathrm{~g})$ was dissolved in $50 \mathrm{ml}$ of heavy paraffin oil (density, 0.89). After centrifugation, to remove undissolved dye, the optical density (O.D.) of the solution was read at $525 \mathrm{~nm}$ after dilution of $0.01 \mathrm{ml}$ ORO solution with $10 \mathrm{ml}$ dioxane; this permitted subsequent conversion of O.D. into $\mathrm{mg}$ of paraffin oil. To prepare the final emulsion. Salmonella LPS [ $10 \mathrm{mg} / \mathrm{ml}$ Krebs-Ringer phosphate (KRP)] was briefly sonicated. To this mixture, the ORO solution was added in a ratio of $3.0 \mathrm{ml}$ LPS to $1.0 \mathrm{ml}$ of ORO solution. This mixture was then sonicated at 1.5 to 2 amps for $90 \mathrm{sec}$.

Opsonization. One-tenth $\mathrm{ml}(0.1)$ of ORO-LPS emulsion was dispensed into $15 \mathrm{ml}$ conical, siliconized centrifuge tubes, and opsonization was initiated by the addition of an equal volume of serum $(0.1 \mathrm{ml})$; tubes were subsequently incubated at $37^{\circ} \mathrm{C}$ for 20 min with periodic gentle shaking. Opsonization was stopped by placing reaction tubes in ice.

Phagocytosis. Eight-tenths $\mathrm{ml}$ of the phagocytic cell suspension was dispensed to opsonized particles, and the mixture incubated at $37^{\circ} \mathrm{C}$ for $5 \mathrm{~min}$ with periodic gentle shaking. Ingestion was stopped by the addition of $6 \mathrm{ml}$ of ice cold $1 \mathrm{mM} N$-ethylmaleimide in normal saline (N.S.). Reaction tubes were centrifuged, and the supernate, which contained undigested emulsion, was discarded. A second wash with $N$-ethylmaleimide was performed, and the tubes were manually cleaned and wiped dry with tissue. Solubilize ingested dye, one $\mathrm{ml}$ (1.0) of p-dioxane (J. T. Baker) was added to the cell pellet to lyse the leukocytes. After lysis of leukocytes and subsequent centrifugation, the supernatant O.D. was read at $525 \mathrm{~nm}$. For initial rates of ingestion, results were expressed as $\mathrm{mg}$ of paraffin oil ingested per $10^{7}$ phagocytes per min using the conversion formula:

$$
\begin{aligned}
& \text { O.D. determined } \times 0.89 \\
& \hline \text { O.D. (standard) } \times \text { number of leukocytes } \\
& \times \text { percentage of phagocytes } \times 5 \text { min }
\end{aligned}
$$

Control experiments with ORO dyes, without added LPS, repeatedly failed to reveal uptake of dye microscopically; ORO without LPS was included as a control with each experiment. Also, heat-treated normal serum was included as a control for each experiment.

Kinetics of Opsonization. To measure the kinetics of opsonization, $0.8 \mathrm{ml}$ of ice cold serum was added to $0.8 \mathrm{ml}$ of ice-cold emulsion in $30 \mathrm{ml}$ round-bottomed centrifuge tubes. Before placement of the emulsion-serum mixture in a $37^{\circ} \mathrm{C}$ water bath, $0.2 \mathrm{ml}$ aliquots were removed for " 0 " time samples and placed into 15 $\mathrm{ml}$ conical centrifuge tubes. After 5, 10,20,40, and $75 \mathrm{~min}$ of incubation at $37^{\circ} \mathrm{C}$, additional $0.2 \mathrm{ml}$ aliquots were removed and also placed into iced centrifuge tubes. All samples were run in duplicate. Phagocytosis was performed identically to the timefixed opsonization.

Sensitivity and Precision of the Opsonization Assay. To determine the sensitivity of the assay, serum was sequentially diluted with 
Krebs-Ringer phosphate, and opsonization and subsequent phagocytosis were performed on the various dilutions of serum, by the methods described. To determine the assay variation, the opsonization ability of a single serum sample was repetitively determined nine and ten times on two separate occasions; the coefficient of variation was determined by standard methods.

Role of Complement and Antibody in Opsonization. Assay for Hemagglutination (HA) Antibody to S. enteritidis LPS. Antibody against LPS was measured by a microhemagglutination technique using sheep RBC's (8). Before determination of antibody titers, all sera were preabsorbed for $2 \mathrm{hr}$ at room temperature with an equal volume of a $10 \%$ suspension of uncoated SRBC's. The antibody titer of each serum was determined utilizing both LPS coated and uncoated SRBC's, and the final titer was recorded as the difference between the two titers, with final titers expressed as the highest serum dilutions resulting in agglutination.

Preparation of $S$. enteritidis LPS Immune Serum. S. enteritidis LPS $(1 \mu \mathrm{g} / \mathrm{ml})$ was suspended in KRP, sonicated, and passed through a 45-micron Millipore filter. Two rabbits received five successively increasing daily doses of LPS $(0.33$ to $1.7 \mu \mathrm{g})$. On the eighth day after the last dose, the rabbits were bled, and the sera was stored at $-20^{\circ} \mathrm{C}$.

Complement Consumption Studies. The ability of $S$. enteritidis LPS to initiate complement consumption was evaluated in five SCD patients and five control subjects. Two children selected from each group had high anti-LPS titers ( $\geq 1: 64)$, and two had low antibody titers $(\leq 1: 4)$; one from each group had intermediate titers. Equal volumes of each tested serum sample plus either LPS $(7.5 \mathrm{mg} / \mathrm{ml})$ in KRP or KRP alone were incubated at $37^{\circ} \mathrm{C}$ for 20 min. The solutions were then cooled to $0^{\circ} \mathrm{C}$, and dilutions were made in veronal buffered saline-glucose buffer (14). Determinations of $\mathrm{C} 1, \mathrm{C} 2, \mathrm{C} 3$, and $\mathrm{C} 4$ activity were made by previously published methods $(10,12,14)$. Factor B conversion was evaluated by immunoelectrophoresis using monospecific goat anti-factor B (Atlantic Antibodies, Westbrook, MN). When calculating the results, the value of the serum KRP mixture was defined as $100 \%$.

Ability of Complement-Depleted Serum to Support Opsonization. Human congenital C2-deficient serum and serum heated to $50^{\circ} \mathrm{C}$ for $20 \mathrm{~min}$, to inactivate factor $\beta$, were opsonized and phagocytosized as described. Normal human serum with an HA titer of 1 : 64 to $S$. enteritidis LPS was depleted of both C4 and factor B by passage through an $\mathrm{Fab}$ immunoabsorbant column in the presence of $10 \mathrm{mM}$ EDTA (Courtesy of Robert Schreiber, M.D., Scripps Clinic, La Jolla, CA). Serum was reconstituted with a solution of 1:5 $\mathrm{mM} \mathrm{CaCl} 2$ in N.S. Opsonization ability and phagocytosis were compared as described in untreated, EDTA, and heat-treated $\left(50^{\circ} \mathrm{C} \times 20 \mathrm{~min}\right)$ and reconstituted aliquots as well as aliquots not reconstituted.

\section{RESULTS}

\section{OPSONIZATION}

Sensitivity and Precision of Assay. Opsonization in sequentially diluted serum demonstrated a direct linear relationship between the amount of LPS-paraffin oil emulsion ingested and serum dilution (Fig. 1). The calculated coefficient of variation for the assay varied from 4 to $13 \%$.

\section{TIME-FIXED OPSONIZATION}

The results of time-fixed $(20 \mathrm{~min})$ opsonization studies are displayed in Figures 2 and 3. There were no detectable differences in the ability of sera to support opsonization between children with SCD and normal children, including children with $A C$ or AS genotypes. Because of interassay variation, results are expressed as $\mathrm{mg}$ of paraffin oil ingested per $10^{7}$ phagocyies per min (Fig. 2) as well as the percentage of variation of each individual serum sample from the control group mean which was determined for each experiment (Fig. 3). For SCD patients, the quantitative opsonization values were from 0.110 to $0.201 \mathrm{mg}$ of paraffin oil

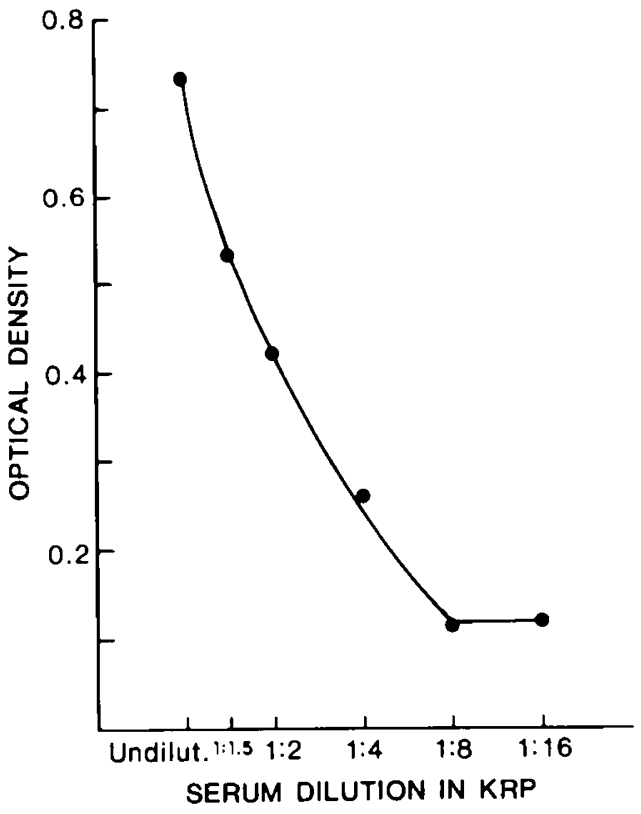

Fig. 1. Relationship of optical density of postingestion ORO extract to serum dilution.

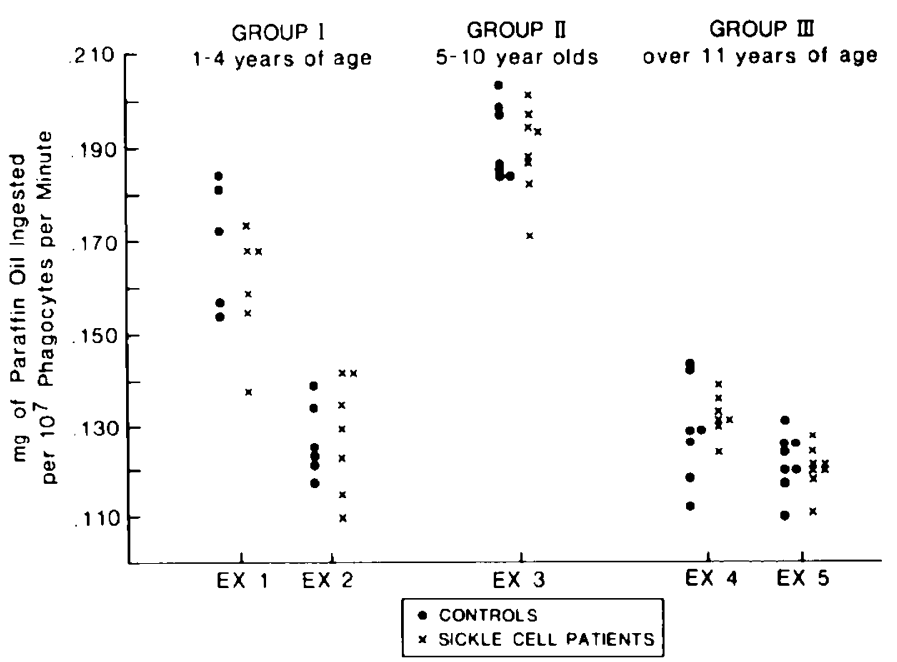

Fig. 2. Comparison of $\mathrm{mg}$ paraffin oil ingested between normal and sickle cell subjects.

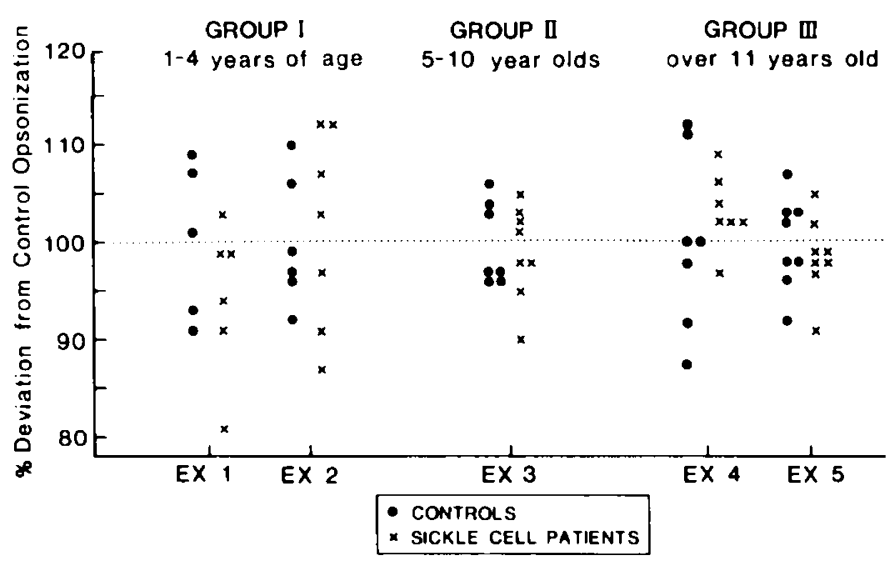

Fig. 3. Comparison of percentage of deviation from mean control values between normal and sickle cell subjects. 
ingested per $10^{7}$ phagocytes per min (mean, 0.146 ). These results were virtually identical to the results for the control children, who had a range of 0.110 to 0.203 (mean, 0.146 ). The percentage of deviation for the control group mean varied from 81 to $112 \%$ in the SCD group and from 88 to $111 \%$ in the control group.

\section{KINETICS OF OPSONIZATION}

No differences were noted in the kinetics of opsonization between three pairs of children evaluated (i.e., control child versus SCD child). A representative curve from one of these pairs of children is depicted in Figure 4. Maximal ingestion was attained

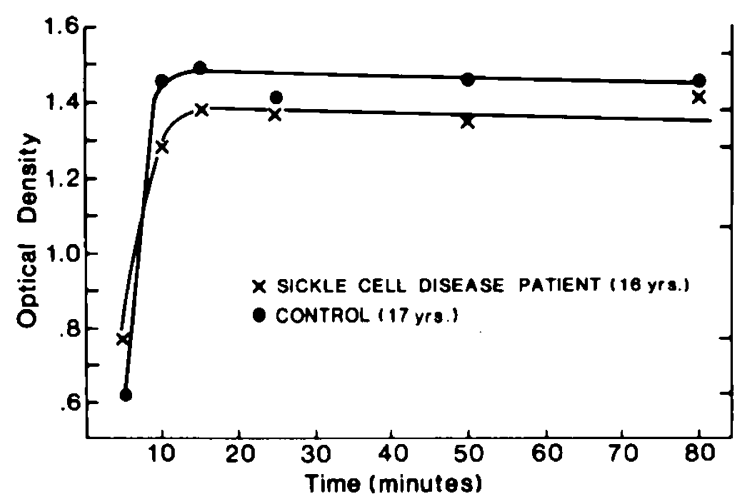

Fig. 4. Example of opsonization kinetics (O.D. of material ingested) in a normal and sickle cell patient.

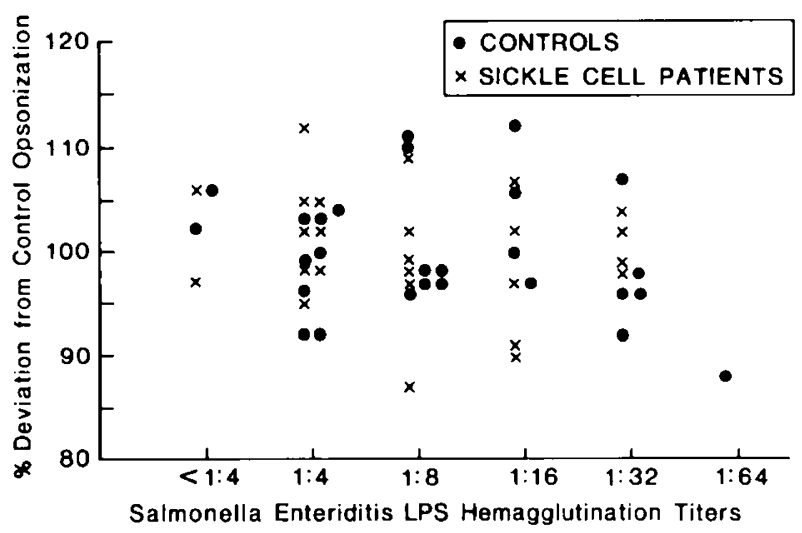

Fig. 5. Comparison of the relation of percentage of deviation from control opsonization to the amount of specific anti-Salmonella antibody in normal and sickle cell disease children. between 10 and $15 \mathrm{~min}$ of incubation in both SCD and normal children.

\section{COMPLEMENT AND ANTIBODY STUDIES}

$H A$ Antibody Titers to $S$. enteritidis LPS. Twenty-five SCD sera and 27 control sera were evaluated for the presence of HA antibody to the LPS. The median titer for the SCD sera was 1:8 (range, 1:4 to 1:32); control sera also had median titers of 1:8 (range, 1:4 to 1:64). There was no correlation between HA titer and the ability to opsonize Salmonella LPS (Fig. 5).

\section{COMPLEMENT CONSUMPTION BY LPS}

The effect of LPS on the consumption of the first four components of complement and factor B was evaluated after incubation of serum with Salmonella LPS or buffer control at $37^{\circ} \mathrm{C}$ for 20 min (Table 1). Under these conditions, Salmonella LPS induced a mean consumption of $0.2 \%$ of $\mathrm{Cl}, 1.1 \%$ of $\mathrm{C} 4,19.2 \%$ of $\mathrm{C} 2$, and $84.6 \%$ of C3 in control and SCD sera. All serum samples had almost total conversion of factor $B$ as determined by visual inspection of the immunoelectrophoretic pattern. There was no correlation between Salmonella HA titers and complement consumption. Further, there were no major differences in complement consumption between the SCD group and control subjects, although there was a trend toward slightly greater $\mathrm{C} 2$ consumption in the latter group.

\section{ABILITY OF COMPLEMENT-DEPLETED SERUM TO SUPPORT ORGANIZATION}

Human serum congenitally deficient in $\mathrm{C} 2$ supported opsonization normally, with values of 75 to $95 \%$ of control. Three sera immunologically depleted of factor B or heated $\left(50^{\circ} \mathrm{C}\right.$ for $\left.20 \mathrm{~min}\right)$ resulted in marked impairment of opsonization, whereas sera depleted of $\mathrm{C} 4$ opsonized normally. Table 2 displays a representative result against a single sera.

\section{DISCUSSION}

In this study, no defect in opsonization of $S$. enteritidis LPS could be detected in the sera of patients with SCD using an assay which appears to be mediated predominantly via the alternative pathway of complement activation. This assumption is supported by the demonstration of normal opsonization in human C2-deficient serum as well as serum depleted of $\mathrm{C} 2$ and $\mathrm{C4}$, whereas serum depleted of factor $B$ and heated serum resulted in marked impairment of opsonization. Our observations on changes of complement factors (Table 1) during opsonization may be limited by the relatively few number of sera included in these experiments.

Table 1. Percentage of change in concentration of $C 1, C 2, C 4$, and $C 3$ after incubation of SCD or normal serum with $S$. enteritidis LPS

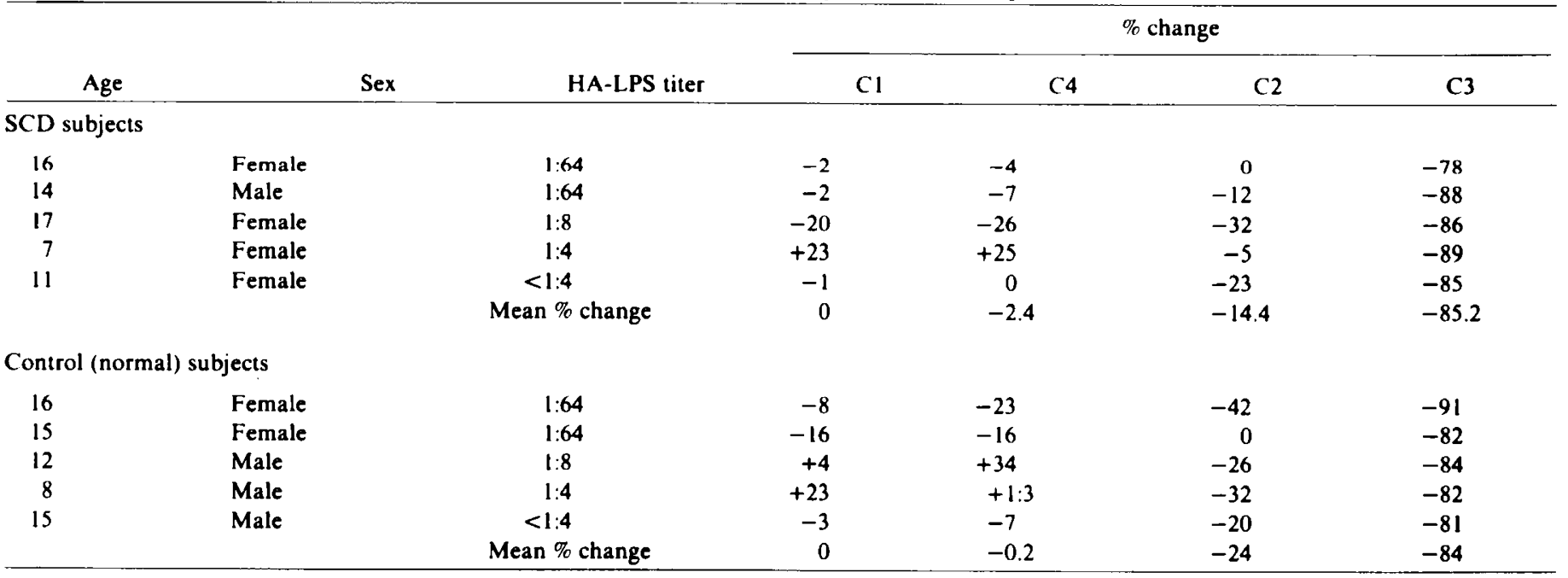


Table 2. Ability of a single representative serum sample to support opsonization after heat treatment, EDTA treatment, C4 depletion, and factor $B$ depletion

\begin{tabular}{lc}
\hline Type of serum treatment & $\begin{array}{c}\text { mg paraffin oil in- } \\
\text { gested } / 10^{7} \text { phagocytes/ } \\
\text { min }\end{array}$ \\
\hline $\begin{array}{l}\text { Untreated serum } \\
\text { EDTA-treated, calcium and magnesium re- } \\
\text { constituted serum }\end{array}$ & 0.196 \\
C4 depleted serum & 0.123 \\
Factor B-depleted serum & 0.172 \\
Heat-activated serum $\left(50^{\circ} \mathrm{C}\right.$ for $\left.20 \mathrm{~min}\right)$ & 0.020 \\
\hline
\end{tabular}

HA titers against Salmonella LPS in sera tested were low; there were no differences in HA titers between SCD and control sera, and no correlation was found between HA titers and the ability of a serum to support opsonization. The observation of a marked consumption of $\mathrm{C} 3$, in association with factor $\mathrm{B}$ conversion and relative sparing of the early complement components $(\mathrm{Cl}, \mathrm{C} 4$, and $\mathrm{C2}$ ), adds further evidence of the dependence of this assay on the alternative pathway. These findings are in accord with the work of Stossel (18) who demonstrated that C2- and C4-deficient sera supported normal opsonization of $E$. coli LPS whereas C3-deficient and cord blood sera (i.e., factor B deficient) failed to support normal opsonization; defects in opsonization could be restored by the addition of the deficient components. Only in the presence of hyperimmune sera was he able to demonstrate a modest increase in the ability to support opsonization.

The finding of normal opsonization of Salmonella LPS in this group is consistent with the work of Winkelstein and Drachman (22) who detected no defect in opsonization of Salmonella choleraesuis in the evaluation of a small group of patients with SCD using an assay similar to the one in which he observed defective opsonization of Streptococcus pneumoniae. However, these experiments are in contrast to the results noted by Hand and King (4) who reported defective opsonization of Salmonella. This discrepancy may be due in part to differences in design of the two studies. In the studies reported here, $S$. enteritidis LPS was utilized for opsonization in contrast to that of viable Salmonella typhimurium which was used by Hand and King (4). The use of viable organisms necessitates the quantitation of ingestion of microorganisms indirectly by enumerating the number of bacteria left in extracellular compartment after phagocytosis. Unfortunately, this may subject the results of such experiments to influences that affect the bacteria other than opsonization such as the interaction with undefined serum factors. Serum factors may directly affect bacterial viability, and in the experiments cited by Hand and King, operation of these undefined factors was suggested by the observation that a concentration of $5 \%$ serum in the absence of phagocytes resulted in a $50 \%$ reduction in viable organisms (4). In contrast to these observations, the same investigators have reported defective killing of $S$. typhimurium in the absence of phagocytosis by SCD sera in a separate report (3). Lastly, dependence on colony counts of viable organisms to quantitate phagocytosis may influence the outcome of experiments due to the intrinsic lack of quantitative precision of microbiologic colony counting which is influenced by many variables (13).

The kinetics of opsonization were evaluated in our studies to test the possibility that children with SCD may opsonize at a different rate than do normal children. In the three patients studied, no differences were noted when compared to normal children. In each, opsonization reached a peak after $15 \mathrm{~min}$ of incubation with serum and plateaued or slowly declined thereafter. Due to the complexity of these experiments, only three SCD were studied; however, kinetic curves are similar to those constructed by Stossel (18) using $E$. coli LPS in normal patients.

Although defects in pneumococcal opsonization have been consistently noted in some patients with $\operatorname{SCD}(2,4,22)$, this has not been true for gram-negative organisms $(2,22)$. This suggests that patients with SCD may have a selective opsonization defect, and the explanation for their increased susceptibility towards Salmonella infection may be different than that for the pneumococcus. The precise nature of the defect in pneumococcal opsonization has not been defined, although it has been suggested that there is defective functioning of the alternative pathway. Bjornson et al. (2) noted that total hemolytic complement, conversion of $\mathrm{C3}$ by inulin or CoVF, and immunochemical measurements of serum levels of factor $\mathrm{B}$, properdin, $\mathrm{C} 3 \mathrm{~b}$ inactivator, and immunoglobulins were normal in children with SCD; the concentration of $\mathrm{C3}$ was slightly reduced, a finding which did not correlate with reduced opsonization. Koethe et al. (8) found reduced activation of complement by CoVF in SCD sera while factor B levels were normal or elevated, suggesting that these patients have reduced factor D activity. Wilson et al. (21) measured factors B and D using a functional hemolytic radial diffusion assay and noted a subgroup of patients with low alternative pathway activity associated with low levels of factor B and normal levels of factor D.

Our study suggests that opsonization of Salmonella LPS is mediated predominantly via the alternative pathway and that in the SCD children evaluated, no abnormalities were detected. The reasons for such diversity of results between reported studies remain unclear; however, in part, the explanation may be related to an incomplete understanding of the complexities of the involved immunologic pathways as well as its interaction with other serum proteins such as antibody, CRP, other complement components, or as yet undefined pathways or factors. Further, it may be that the alternative pathway is quantitatively more important in pneumococcal infections, and therefore, small defects are more apparent in vitro. The available evidence to date suggests that if the patient with SCD does have a defect in the function of the alternative pathway, it is probably a minor determinant in his propensity toward Salmonella infections.

\section{REFERENCES AND NOTES}

1. Barret-Connors, E.: Bacterial infections and sickle cell anemia. Medicine (Baltimore). 50: 97 (1971).

2. Bjornson. A. B., Gaston, M. H., Zellner, C. L.: Decreased opsonization of Streptococcus pneumoniae in sickle cell disease. Studies on selected complement components and immunoglobulins. J. Pediatr., 91: 371 (1977).

3. Hand, L. W., and King. N. L.: Deficiency of serum bacterial activity against Salmonella typhimurium in sickle cell anemia. Clin. Exp. Immunol.. 30: 262 (1977).

4. Hand, L. W., and King. N. L.: Serum opsonization of salmonella in sickle cell anemia. Am. J. Med. 64: 388 (1978).

5. Hook. E. W., Campbell, C. G., Weens, H. S., and Cooper, G. R.: Salmonella osteomyelitis in patients with sickle cell anemia. N. Engl. J. Med., 257: 403 (1957).

6. Johnston, R. B.: Increased susceptibility to infection in sickle cell disease: review of its occurrence and possible causes. South. Med. J., 67: 1342 (1974).

7. Johnston, R. B., Jr., Newman, S. L., and Struth, A.: An abnormality of the alternative pathway of complement activation in sickle cell disease. N. Engl. J Med.. 288: 803 (1973).

8. Koethe, S. M., Casper, J. T.. and Rodey, G. E.: Alternative complement pathway activity in sera from patients with sickle cell disease. Clin. Exp. Immunol.. 23: 56060 (1976).

9. Neter. E., Whang, H. and Mayer. H.: Immunogenecity and antigenicity of endotoxic lipopolysaccharides: reversible effects of temperature on immunogenicity, in bacterial lipopolysaccharides. J. Infect. Dis. 128 (Suppl. 56-60) (1973).

10. Opferkuck, W., Rapp, H. I., Colten, H. R., and Borsos, T.: Immune hemolysis and the functional properties of the second $(\mathrm{C} 2)$ and fourth $(\mathrm{C} 4)$ components of complement. II. Clustering of effective $\mathrm{C} 43$ complexes at individual hemolytic sites. J. Immunol., 106: 407 (1971).

11. Overturf, G. D., Powars, D., and Baraf,, L. J.: Bacterial meningitis and septicemia in sickle cell disease. Am. J. Dis. Child., 131: 784 (1977).

12. Pinckard, R. N., Olson, M. R., Giclas, C. G., Terry, R., Boyer, J. T., and O'Rourke, R. A.: Consumption of classical complement components by hear subcellular membranes in vitro and in patients after myocardial infarction. $J$ Clin. Invest., 56: 740 (1975).

13. Postgate. J. R.: Viable counts and viability. In: J. R. Norris and D. W. Ribbons: Methods in Microbiology, Vol. I. Chap. 18. (Academic Press, Inc.. New York. 1969).

14. Rapp, H. J., and Borsos. T.: Molecular basis of complement action. (AppletonCentury-Crofts. New York, 1972).

15. Robinson. M. G., Watson, R. J.: Pneumococcal meningitis in sickle cell anemia. N. Engl. J. Med.. 274: 1006 (1966)

16. Seeler, R. A., Metzger, W., and Watson. M. A.: Diplococcus pneumoniae infections in children with sickle cell anemia. Am. J. Dis. Child., 123: 8 (1966). 
17. Silver, H. K.. Simon, J. L., and Clement, D. H.: Salmonella osteomyelitis and abnormal hemoglobin disease. Pediatrics, 20: 439 (1957).

18. Stossel, T. P.: Evaluation of opsonic and leukocye function with spectrophotometric test in patients with infection and with phagocytic disorders. Blood, 43: 121 (1973).

19. Strauss, R., Asbrook, T., Forristal, J., and West, C.: Alternative pathway of complement in sickle cell disease. Pediatr. Res., 11: 285, 289 (1977).

20. Weinberg. E. D.: Iron and infection. Microbiol. Rev., 43: 45 (1978).

21. Wilson, W., Hughes, G., and Lachmann, P.: Deficiency of factor B of the complement system in sickle cell anemia. Br. Med. J., 1: 767 (1976).

22. Winkelstein, J. A., and Drachman, R. H.: Deficiency of pneumococcal opsonizing

Copyright (C) 198 I International Pediatric Research Foundation, Inc. 0031-3998/81/1502-0107\$02.00/0 activity in sickle cell disease. N. Engl. J. Med., 279: 459 (1968).

23. The authors would like to acknowledge the advice and assistance of Dr. Darleen Powars, Professor of Pediatrics, USC, Los Angeles, CA, and Dr. Robert Schreiber, Scripps Institute, La Jolla, CA

24. Requests for reprints should be addressed to: Gary D. Overturf, M.D. Los Angeles, County/USC Medical Center, Pediatric Pavlion, 1129 N. State Street, Los Angeles, CA 90033 (USA)

25. This research was supported by Sickle Cell Grant HL 15162 and the National Heart, Lung, and Blood Institute.

26. Received for publication February 19, 1980

27. Accepted for publication May 23, 1980. 